\title{
Evidence of Quartz, Feldspar and Amphibole Crystal Plastic Deformations in the Paleoproterozoic Nyong Complex Shear Zones Under Amphibolite to Granulite Conditions (West Central African Fold Belt, SW Cameroon)
}

\author{
Sébastien Owona ${ }^{1}$, Joseph Mvondo Ondoa ${ }^{2} \&$ Georges Emmanuel Ekodeck $^{1}$ \\ ${ }^{1}$ University of Douala, Department of earth Sciences, Douala, Cameroon \\ ${ }^{2}$ University of Yaounde I, Department of earth Sciences, Yaounde, Cameroon \\ Correspondence: Sebastien Owona, Department of earth Sciences, University of Douala, P. O. Box: 24157, \\ Douala, Cameroon. Tel: 237-74-014-096, 237-33-139-130. E-mail: owonas2012@gmail.com, \\ owonas@univ-douala.com
}

Received: July 8, 2013 Accepted: August 14, 2013 Online Published: August 19, 2013

doi:10.5539/jgg.v5n3p186 URL: http://dx.doi.org/10.5539/jgg.v5n3p186

\begin{abstract}
The Paleoproterozoic is characterised by a global-scale period of crust formation, extensive mafic to granitic magmatism, crustal reworking and intracrustal partial melting. Since a dramatic strength drop is associated with the presence of melt in crystallising or melting rocks, Paleoproterozoic continental deformation is thought to have been largely accommodated by shearing of high-grade gneisses and syntectonic granitoids. The Paleoproterozoic Nyong complex, which is made up of volumetrically dominant granitoids, metapelites and granitic gneisses, quartzites and banded iron formations; has been affected by the Eburnean/Transamazonian polyphase ductile and brittle deformation responsible of $S_{1 / 2}$ foliation and $S_{2}$ schistosity, $L_{2}$ stretching and mineral lineations, $\mathrm{F}_{3}$ meso- and large-scale folds, $\mathrm{S}_{2} / \mathrm{C}_{3}$ structures and faults. Its shear zone strain anisotropies represent a natural laboratory to study the effect of crystal plastic deformation of felsic minerals and amphibole as predicted by numerical experiments and tectonic models. This paper describes the geometry of the deformation and focus on microstructural evidence of dynamic recrystallization features that were active under granulite conditions $\left(>800{ }^{\circ} \mathrm{C},>8.5 \mathrm{Kbar}\right)$. These thermal conditions can be extended in similar Proterozoic worldwide shear zones.
\end{abstract}

Key words: Paleoproterozoic, Eburnean/Transamazonian, shear zones, crystal plastic deformations, P-T, Nyong complex, SW Cameroon

\section{Introduction}

Geological and geophysical boundaries show that deformation in the Earth's crust is heterogeneous, with large displacements confined into faults and shear zones. Since last decades, significant progress has been made in understanding the microstructural evolution of crystallizing or melting rocks in natural and numerical experiments and tectonic models (e.g. While, 1973, 1977; Urai et al., 1986; Vernon, 2000; Hirth et al., 2001; Stipp et al., 2002; Passchier \& Trouw, 2005; Zibra et al., 2010, 2012; Zibra, 2012). A close spatial and temporal relationship between pluton emplacement and shear zones has been documented in various geological settings (see Rosenberg, 2004 for a review; Weinberg et al., 2004). Shear zones display microstructurally very different strain anisotropy to protoliths. They are associated to mineral dynamic recrystallizations where magmatic and metamorphic textures are overprinted by later deformations or annealing processes and the physical conditions (pressure, temperature, strain rate, differential stress, and water content). They offer to geologists, best examples of mineral recrystallization from microscopic to mesoscopic and megascopic scales. These deformations may differ from one portion to another through different fabrics, reflecting subsequent stages of syndeformational crystallization. Therefore, interpretation of microstructure and orientation and intensity of fabrics is critical in order to constrain space/time/temperature/deformation relationships during rock crystallization (Stipp et al., 2002).

The Nyong complex made up of granitoids, high-grade gneisses, quartzites, banded iron formations and 
greenstone rock types that have experienced the Eburnean/transamazonian orogeny (e.g. Maurizot et al., 1986; Nédélec et al., 1993; Feybesse et al., 1998; Penaye et al., 2004). Herein, we present its new structural data at the western border of the Congo Craton. In particular, we focus on dynamic recrystallizations and apply its mechanisms with reference to natural deformation microstructures in quartz, feldspar and amphibole and with respect of the inferred deformation temperature from the Nyong complex shear zones in comparison to undeformed protoliths (Figure 1). For these objectives, we used the light microscopy and standard methods of microfabric analysis (Passchier \& Trouw, 2005) and models of crystal plastic deformation of quartz (Stipp et al., 2002) and feldspar (Kurse et al., 2001).

\section{Material Studied}

Oriented samples (Figure 2) from the NyC foliations and shear zones were sampled in Mbigame (Ow294), Angonfeme (Ow309) and Akongo (Ow310) clinopyroxene syenites for the Akongo group. The Kama group was sampled on Abang Betsenga (Ow374) and Akok (Ow326) metagranodiorites, Enguingli gneisses (Ow354) and Abang-Betsenga banded iron formation (BIF). Above samples were prepared for XZ high-quality slides for petrographical and microtectonic studies, especially quartz, feldspar and amphibole plastic deformations. Investigations were carried out on a Leica LMP microscope of the Institute of Geology TU-Freiberg in Germany. Mineral abbreviations are from Kretz (1983). These petrographical and microtectonic studies focused on metagranodiorites and synkinematic syenites, the main rock types for the Kama and Akongo groups, respectively.

\section{Geological Setting}

The SW Cameroon consists of the Ntem, Nyong and Oubanguide complexes (Owona et al., 2011, Figures 1a, b). The Ntem complex (NC) corresponds to Cameroonian part of the Congo craton of Archean age whereas the Oubanguide complex (OC) or Central African Fold Belt (CAFB) results from the Neoproterozoic collision between the Congo, West African and?Chad cratons or the Saharan metacraton (Castaing et al., 1994; Toteu et al., 1994; Trompette, 1994; Feybesse et al., 1998; Abdelsalam et al., 2002; Oliveira et al., 2006).

The Nyong Complex (NyC) studied here, results from the Eburnean/Transamazonian tectonothermal event (2400-1800 Ma) associated to the collision between the Congo and São Francisco cratons (Nédélec et al., 1993; Feybesse et al., 1998; Lopez et al., 2001; Penaye et al., 2004; Lerouge et al., 2006; Neves et al., 2006; Owona et al., 2011). It belongs to the Paleoproterozoic mobile belt or West Central African Fold Belt (-WCAFB-, Feybesse et al., 1998), which includes other provinces such as Franceville-Ogoué in Gabon, West Congo in Republic of Congo and Carnot basin in the Central African Republic (Poidevin \& Pin, 1986; Bassot et al., 1987; Morin et al., 1991; Caen-Vachette et al., 1988; Owona, 2008). The WCAFB equivalent lithostructural units are the Unbendian Province in Tanzania in East Africa (Boniface et al., 2012), the Borborema and Oaxaquia Provinces in NE Brazil and Mexico (Lopez et al., 2001; Neves et al., 2006).

The NyC includes the Kama, Akongo and Ngovayang groups. The Kama group consists of tonalite, trondhjemite, granodiorite (TTG), anorthosite, charnockite, gneiss, migmatite, eclogite, metagabbro, and quartzite or banded of iron formation (BIF). The Akongo group is comprised of two-pyroxene and clinopyroxene syenites, amphibolite, metagabbro, migmatite, garnetite and BIF. The Ngovayang group includes charnockite, gneiss, migmatite, amphibolite, garnetite, metagabbro, quartzite and BIF. According to Tchameni et al. (2001), clinopyroxene syenites are differentiated into mafic and felsic syenites where mafic syenites are predominantly composed of diopside-hedenbergite Cpx series whereas felsic clinopyroxene syenites consist primarily of perthitic alkali feldspar. These protoliths are dissected by shear zones and faults. Those studied here are magnetite-bearing quartzites, metagranodiorites and syn-kinematic syenites.

The NyC was affected by a $\mathrm{D}_{1}-\mathrm{D}_{3}$ polyphase deformation (Feybesse et al., 1998; Owona et al., 2011). The $\mathrm{D}_{1}$ deformation is represented by the $S_{1}$ foliation preserved in hinges of $F_{2}$ folds. This deformation is overprinted by the $\mathrm{D}_{2}$ simple shear deformation during which peaked the Eburnean/Transamazonian amphibolite-granulite tectonothermal event at ca. 2050 Ma (SHRIMP U/Pb-Zr, Nédélec et al., 1993; Toteu et al., 1994; Lerouge et al., 2006). $D_{2}$ emplaced the $S_{2}$ foliation, $L_{2}$ lineations and $F_{2}$ folds (Maurizot et al., 1986; Minyem, 1994; Feybesse et al., 1998). $\mathrm{D}_{3}$ displays $\mathrm{F}_{3}$ large-scale folds that define the Paleoproterozoic Nyong nappe transported toward the East onto the $\mathrm{NC}$ and $\mathrm{C}_{3} \sim \mathrm{SW}-\mathrm{NE}$ sinistral blastomylonitic shear zones (Minyem, 1994; Owona et al., 2011). The brittle phase is post-Eburnean-Transamazonian. It emplaced SW-NE faults reactivated during the Pan-African orogeny (Penaye et al., 2004). 

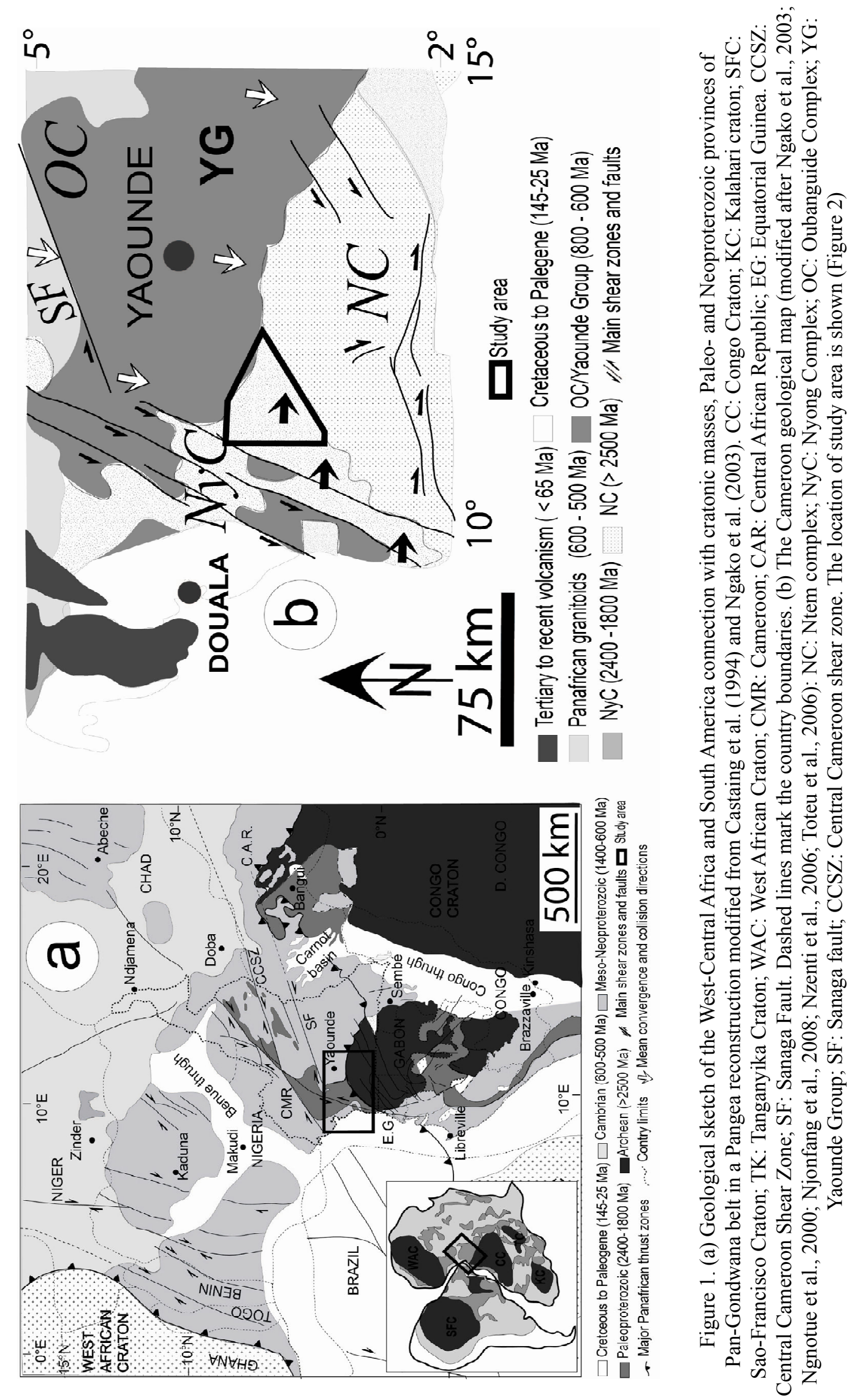

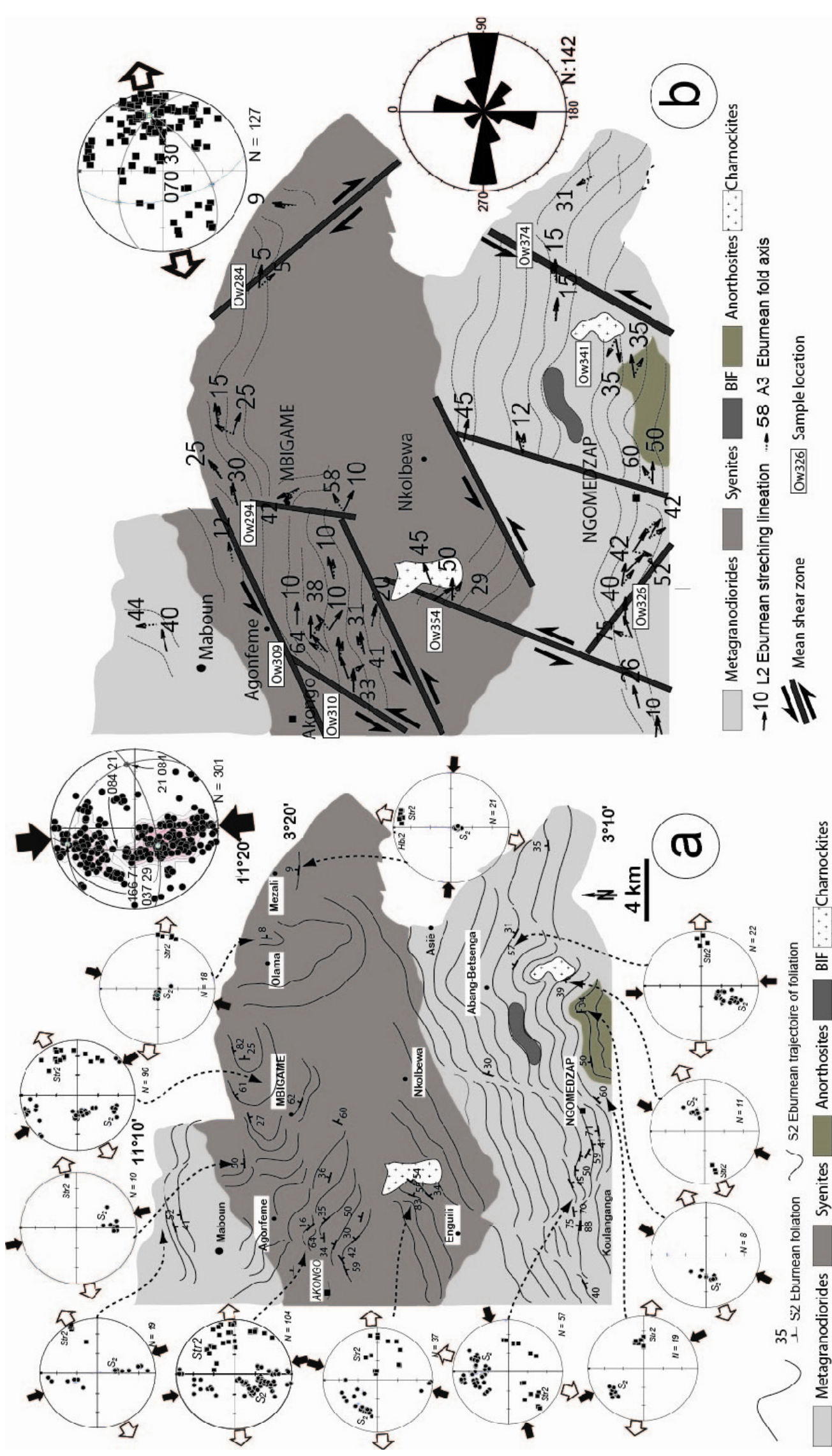

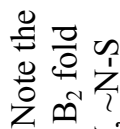

के

ธิ้.

卷 䒕

.

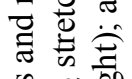

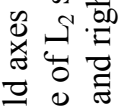

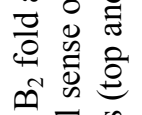

की का है

.:

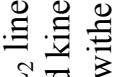

Uิ

乙品

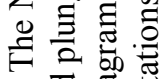

อิ

ธี

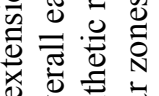

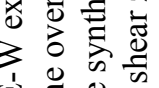

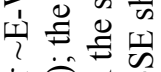

泀高吾方

吾苛

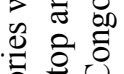

. ڤ્ق

. छ

폽 옴

ㅎํ항

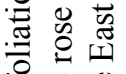

놀

สิ

ㅎํ के

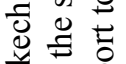

ज㐫 है

.0

응 -

$\infty$ 흥 임

듀.

乙 ज्ञ

ㄱ. 응

0
0
0
0
0
0
0 
The Eburnean/Transamazonian metamorphism began early in Gabon where it's well documented and peaked at ca. $2100 \mathrm{Ma}$ (U/Pb-zircon, Caen et al., 1988), between $600-700^{\circ} \mathrm{C}, 6-10 \mathrm{kbar}$ in Ayem metapelites (Ledru et al., 1994; Feybesse et al., 1998); $650{ }^{\circ} \mathrm{C}$ and 7.5 kbar in Ndjole-Nkan-Nkolissen amphibolites (Feybesse et al., 1998). This orogeny began slight later in the NyC (Cameroon) at ca. $2050 \mathrm{Ma}$ (U/Pb-Zircon, Toteu et al., 1994). It peaked under amphibolites to granolithic conditions $530-750{ }^{\circ} \mathrm{C}, 4-9 \mathrm{kbar}$ in Eseka migmatite (Nédélec et al., 1993); $872{ }^{\circ} \mathrm{C}, 8.22 \mathrm{kbar}$ in Olama syntectonic syenites; $662{ }^{\circ} \mathrm{C}, 14.79 \mathrm{kbar}, 1040{ }^{\circ} \mathrm{C}, 9.5 \mathrm{kbar}$ in Akongo and Nkolbewa metagabbros (Owona, 2008). The retrograde phase defined by the amphibole-biotite-epidote and amphibole-chlorite-epidote assemblages (Nédélec et al., 1993; Owona, 2008).

\section{Methods}

Samples were prepared for XZ high-quality slides for petrographical and microtectonic studies, especially quartz, feldspar and amphibole plastic deformations. Investigations were carried out on a Leica LMP microscope of the Institute of Geology TU-Freiberg in Germany. Mineral abbreviations are from Kretz (1983). These petrographical and microtectonic studies focused on metagranodiorites and synkinematic syenites, the main rock types for the Kama and Akongo groups, respectively.

Bedding $\left(S_{0}\right)$, foliation $\left(S_{n}\right)$, lineation $\left(L_{n}\right)$, axial planes of folds $\left(F_{n+1}\right)$, fold axes $\left(B_{n+1}\right)$, S-C foliation-shear fabrics and faults were identified and measured in outcrops. The foliations were classified by the metamorphic minerals that define them. Stretching lineations as ripple marks and flow lines were measured for kinematical and geometrical criteria. Optical microscopy was applied in standard thin sections oriented parallel to XZ sections of the finite strain ellipsoid (normal to the foliation and parallel to the stretching lineation) to select microstructures indicating ductile deformation and identify critical metamorphic mineral assemblages as well as to guide quartz, feldspar and amphibole dynamic recrystallization features and mechanisms associated to temperature conditions (Kurse et al., 2001; Stipp et al., 2002; Passchier \& Trouw, 2005).

Dynamic or plastic recrystallizations were defined as deformation-induced reworking of grain sizes, shapes or orientations with little or no chemical change (Guillopé and Poirier, 1979). These happened when the primary or protolith mineral recrystallization temperature intervals is reached later during tectonothermal events. Plastic recrystallized minerals display several microstructures such as bulging (BLG), sub grain rotation recrystallization (SGR), grain boundary migration (GBM) and sub grain area reduction (SGAR) from low-, medium-, high- to highest-temperatures, respectively (Figure 3). The BLG that occurs at lower temperature consists of micrometric local slow boundary migration or apophyses into or out of porphyorclasts. It undergoes progressive SGR with separation from old grain by bridging sub grain boundary or new and small grain apparitions surrounding old cores under medium temperature. The GBM that occurs at high-temperature, are characterized by undulated mineral boundaries. The SGAR defines the final plastic deformation stage of the old mineral under highest temperature conditions. New and small grains with undulated boundaries disappeared for idiomorphic blasts with triple points replacing the old core minerals. Details of dynamic recrystallization stages and mechanisms can be consulted in Kurse et al. (2001), Stipp et al. (2002), Passchier and Trouw (2005), Zibra (2010, 2012), Zibra et al. (2012). If these assertions are accepted, plastic recrystallizations define a reworked deformation affecting primary minerals such as porphyroclasts and porphyroblasts. 


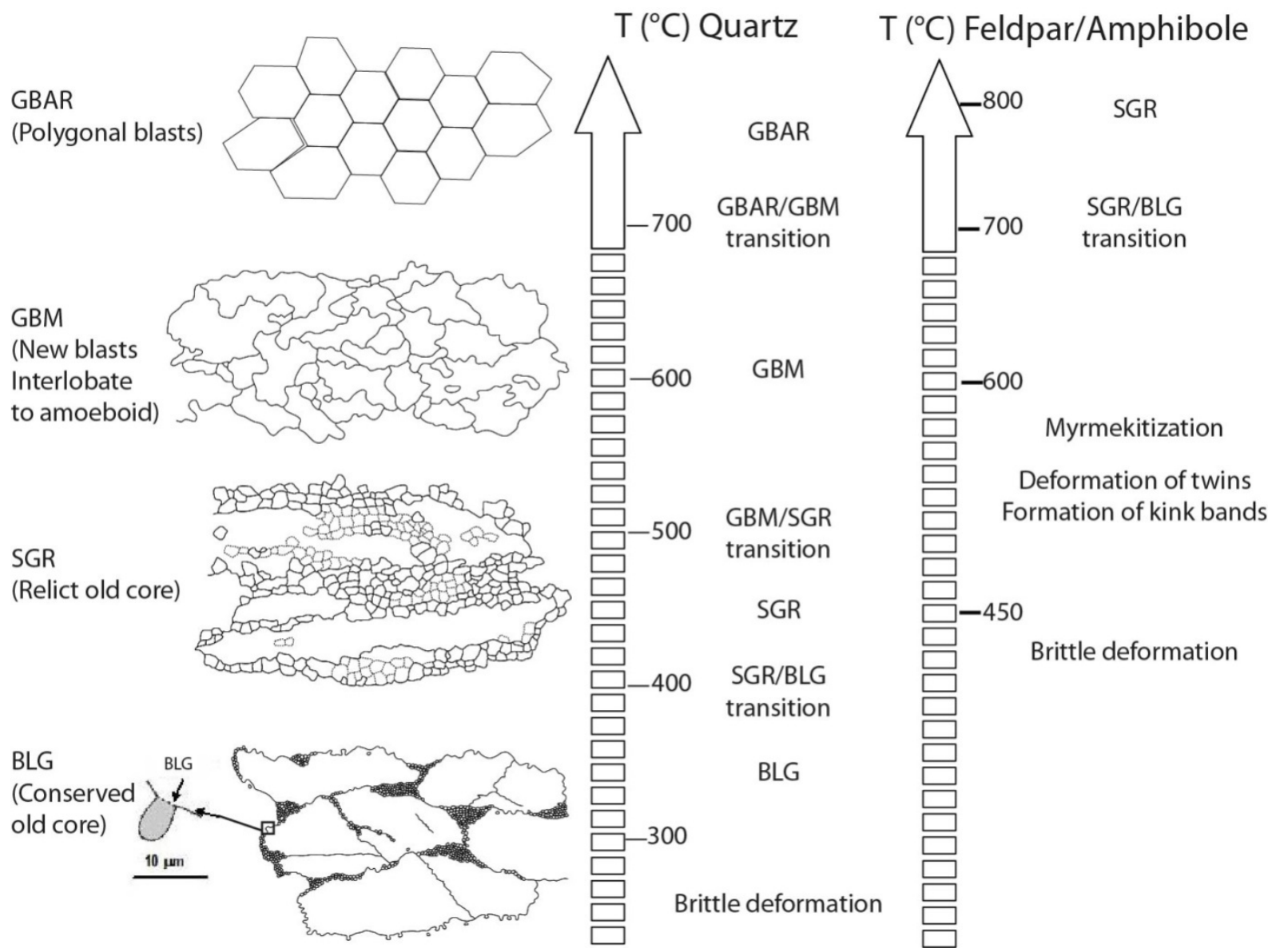

Figure 3. Prototype of dynamic recrystallization features and related temperature conditions. (a) Bulging recrystallization (low T): Bulges and recrystallized grains are present along grain boundaries and to a lesser extend along microcracks. (b) Subgrain rotation recrystallization (intermediate T): core and mantle structures of porphyroclastic ribbon grains and recrystallized subgrains. Polygonizatiion by progressive subgrain rotation can completely consume the ribbon grains. (c) Grain boundary migration recrystallization (high T): Irregular grain

shapes and grain sizes; grain boundaries consist of interfingering sutures. (d) Subgrain area reduction recrystallization (Highest T): Grain boundary adjustment and grain growth, resulting in a decrease in grain boundary energy and straightened to a polygonal shape with elimination of small grains. (Modified after Kurse et al., 2001; Stipp et al., 2002; Passchier \& Trouw, 2005)

\section{Results}

\subsection{Petrography}

\subsubsection{Magnetite-Bearing Quartzites}

Magnetite-bearing quartzites correspond to BIF. They show red colour, foliation and composed mainly of quartz and opaques in hand sample. Under the microscope (Figure 4a), BIF are mesocratic with a granoblastic texture, composed essentially of quartz and magnetites with accessories, muscovites and detrital zircons. Quartz (1-3 mm) is represented by hypidio- to idiomorphic coarse to stretched blasts. It is polycrystalline defining the SGAR fabric with undulose and patchy extinctions. They form quartzite layers corresponding to the composite $\mathrm{S}_{1 / 2}$ foliation that derived from the transposition of $S_{1}$ in $S_{2}$ during $D_{2}$. Quartz also forms the $L_{2}$ mineral and stretching lineations and contains zircon inclusions. Magnetites $(0.5-2 \mathrm{~mm})$ outline isolated or mineral aggregate blasts. They form discontinuous mafic layers equivalent to $S_{1 / 2}$ foliation too. Magnetites are stretched parallel to quartz band ribbons and form the $\mathrm{L}_{2}$ stretching and mineral lineations whereas muscovite $(1-2 \mathrm{~mm})$ participates in the felsic layers. The magnetite-bearing quartzites define two mineral associations, (1) sedimentary paragenesis symbolized by the association quartz $1+$ magnetite $1+$ zircon and equivalent to the $\mathrm{s}_{0 / 1}$ foliation and, (2) metamorphic paragenesis characterised by the association quartz $2+$ magnetite $2 \pm$ muscovite corresponding to the $\mathrm{S}_{2}$ foliation. 


\subsubsection{Metagranodiorites}

In outcrops and hand samples, metagranodiorites protoliths are clear, massive to banded rock types with a sub-vertical foliation. In XZ slides, they are leucocratic and show porphyro-granoblastic texture (Figure 4b). They consist predominantly of quartz, microcline, plagioclase $\left(\mathrm{An}_{20-40}\right)$, biotite, green amphibole and opaques. Diopside, muscovite, apatite, epidote, sericite, calcite and zircon are accessories. Plagioclase is subhedral to euhedral and antiperthitic $(0.5-1 \mathrm{~mm})$ with quartz, opaque and zircon inclusions. It is transformed into epidote. Quartz $(0.5-2 \mathrm{~mm})$ defines polycrystalline ribbon and anhedral recrystallized blasts with undulose and patchy extinctions. Biotite flakes $(0.5-1 \mathrm{~mm})$ rich in opaque inclusions are subhedral and kinked. Microcline occurs as perthititic and recrystallized blasts. Green amphibole $(0.5-1 \mathrm{~mm})$ displays subhedral blasts, retromorphosed into epidote and calcite in inner zones and cracks. Opaques form amoeboid to prismatic inclusions in amphibole. Apatite includes euhedral-aligned microblasts, whereas calcite $(<0.5 \mathrm{~mm})$ appears as inclusions in amphibole. Round zircons $(<0.5 \mathrm{~mm})$ are encountered as inclusions in biotite and feldspar. Metagranodiorite protoliths include 03 parageneses, (1) the magmatic (quartz + plagioclase + diopside + microcline \pm opaques \pm apatite \pm zircon); (2) the metamorphic (quartz + plagioclase + amphibole + biotite \pm microcline \pm opaques) and; (3) the retromorphic (muscovites \pm calcite \pm epidote \pm sericite).

\subsubsection{Syn- $\mathrm{D}_{2}$ Clinopyroxene Syenites}

Syn- $\mathrm{D}_{2}$ clinopyroxene syenites are pink to pink-clear and massive to banded rocks in outcrops and hand samples, where amphibole and feldspar are recognizable. Under the microscope (Figure 4c), they are mesocratic with inequiangular granoblastic texture, predominantly composed of microcline, actinolite, omphacite, albite and quartz. Apatite, titanite, ilmenite, magnetite and zircon are accessories, whereas epidote, sericite, muscovite and calcite are secondaries. Microclines consist of old magmatic cores $(0.05-5 \mathrm{~mm})$. Actinolites compose of magmatic grains $(0.05-2 \mathrm{~mm})$ and retromorphic blasts that derived from the uralitization of pyroxene are pseudomorphosed in calcite. Omphacite $(0.02-0.1 \mathrm{~mm})$ is by bordered by green amphibole corona. Plagioclase and quartz are micrometric in size. Biotites $(0.05-0.2 \mathrm{~mm})$ define idiomorphic inclusions in actinolite and are kinked. Apatite includes subhedral to euhedral grains $(<0.5 \mathrm{~mm})$. Opaques $(<0.5 \mathrm{~mm})$ are represented by subhedral to euhedral minerals as inclusion in amphibole and clinopyroxene. Zircon occurs as inclusions in microcline and hornblende. Clinopyroxene syenite protoliths show two mineral assemblages, (1) the magmatic (quartz + plagioclase + microcline + actinolite + biotite \pm opaques \pm apatite \pm ilmenite \pm magnetite \pm zircon) and (2) metamorphic (omphacite + epidote \pm calcite \pm sericite \pm titanite).
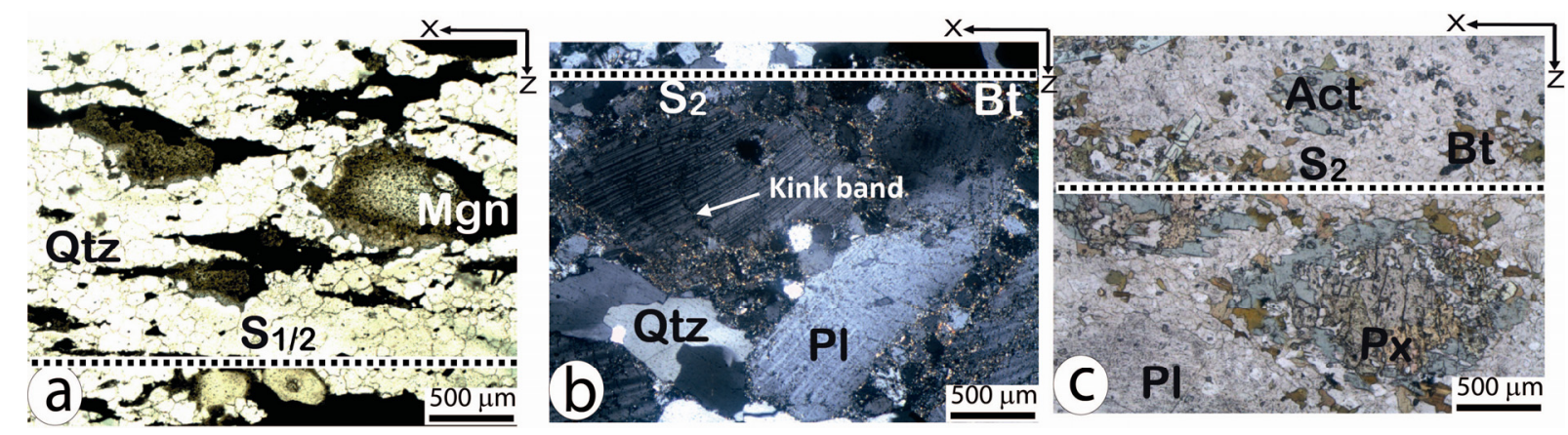

Figure 4. Micrographs of magnetite-bearing quartzite, metagranodiorite and syntectonic clinopyroxene syenite protoliths. Note (b) coexistence of old magmatic plagioclase and metamorphic quartz, (c) the ouralitization of pyroxene

\subsection{Tectonics}

\subsubsection{Foliations}

Two foliation types, $S_{0 / 1 / 2}$ in BIF and paragneisses and, $S_{2}$ in pre- to syntectonic granitoids are encountered within the NyC. The $\mathrm{S}_{0}$ bedding is completely transposed to the $\mathrm{S}_{0 / 1}$ foliation during first deformation phase $\mathrm{D}_{1}$. $\mathrm{S}_{0 / 1}$ relict foliation is preserved in hinges of $\mathrm{F}_{2}$ intrafolial rootless folds. It is a typical millimetric to centrimetic gneissic foliation, defined by the shape preferred orientation of biotite, muscovite, ribbon quartz and feldspar; ribbon quartz, magnetite and muscovite in BIF microscopically. Parageneses quite similar, attest to transposition of $S_{0 / 1}$ foliation is during the $D_{2}$ deformation phase to the composite $S_{0 / 1 / 2}$ foliation. The $S_{2}$ foliation is axial 
planar to folded veins concentrated at edges of mesoscopic boudins. It forms melanocratic and leucocratic layers in metagranodiorites, syntectonic clinopyroxene syenites. Microscopically, $\mathrm{S}_{2}$ foliation is represented by quartz + plagioclase + amphibole + biotite \pm microcline \pm opaques paragenesis in metagranodiorites and, quartz + plagioclase + microcline + omphacite + actinolite + biotite \pm opaques \pm apatite \pm titanite + ilmenite + magnetite + zircon in synkienatic syenites. Both $\mathrm{S}_{0 / 1 / 2}$ and $\mathrm{S}_{2}$ foliations are mainly oriented WSW-ENE to N-S, sub-parallel to magmatic and metamorphic layering limited by blastomylonitic S/C shear zones. Their average values correspond to northern and southern sides are oriented to 03729 and 16671 respectively. These sides defined $\mathrm{F}_{3}$ large-scale fold (Figure 2a).

\subsubsection{Lineations}

$\mathrm{L}_{2}$ includes stretching and mineral lineations. The $\mathrm{L}_{2}$ stretching lineation developed during $\mathrm{D}_{2}$, is defined by elongate ribbon quartz and magnetites, quartzo-feldspathic aggregates, stretched and boudinaged feldspars. The $\mathrm{L}_{2}$ mineral lineation is outlined by prismatic amphibole in synkinematic syenites. Both lineations are parallel, oriented WSW-ENE to WNW-ESE with an average value of $07030 . \mathrm{B}_{2}$ fold axes display similar plunges (Figure 2b).

\subsubsection{Shear Zones}

Shear zones are characterised by their fine grain sizes and anisotropy on the contrary of protoltihs and their $S_{n}$ foliation (Figures 2a, b). They constitute one of the main structural imprints of the late-tectonic $\mathrm{D}_{3}$ phase and the cooling stage. They are grey to light grey show by alignment of dominant felsic and mafic minerals and secant or parallel to the foliation, oriented mainly $\sim \mathrm{E}-\mathrm{W}, \mathrm{NE}-\mathrm{SW}$, NNE-SSW. They dissect protoliths as well as the $\mathrm{S}_{\mathrm{n}}$ foliation, $\mathrm{F}_{3}$ meso- and large-scale folds, $\mathrm{L}_{2}$ stretching and mineral lineations, $\mathrm{B}_{2}$ boudins, feldspathic and quartzo-feldspathic lenses that characterised the $\mathrm{D}_{2}$. They define $\mathrm{S}-\mathrm{C}$ structures and $\mathrm{S}_{3}$ schistosities.

In magnetite-bearing quartzites, metagranodiorites and clinopyroxene syenites, shear zones show from outer to inner zones, drop of magmatic or metamorphic grain sizes, equivalent to the raise of crystal plastic deformation stages. In BIF and metagranodiorites, metamorphic quartz and feldspar represented by secondary fine grains size blasts, recrystallized dynamically, progressively until the primary or protolith minerals complete disappearance.

In clinopyroxene syenites, from outer to inner zone, quartz, feldspar and actinolite display increase of crystal plastic deformation stages. They define the recrystallized anisotropy of shear zone fabrics in which, old protolith magmatic minerals are progressively replaced by secondary fine grain size ones, until their complete disappearance.

Shear zones display the following crystal plastic deformation mineral assemblages: (1) quartz $2+$ magnetite $2 \pm$ muscovite in magnetite-bearing quartzites, (2) plagioclase + quartz + microcline \pm opaques \pm biotite in metagranodiorites and, (3) quartz \pm plagioclase + microcline \pm actinolite \pm biotite \pm titanite + ilmenite + magnetite in clinopyroxene syenites.

\subsection{Crystal Dynamic Recrystallizations}

\subsubsection{Quartz}

Quartz displays different dynamic recrystallization features in protoliths and shear zones from outer to inner zones (Figures 5, 6). In outer zones of metagranodiorites and BIF protoliths, quartz fabrics consist of metamorphic quartz2 blasts. They derived from the recrystallization of quartz1 clasts, relict $\mathrm{D}_{1}$ and $\mathrm{S}_{1}$ foliation into quartz2 during the $\mathrm{D}_{2}$ in BIF (Figures $5 \mathrm{a}, \mathrm{b}$ ). These quartz2 $(\geq 2 \mathrm{~mm}$ ) are lengthened and hypidiomorphic blasts with undulose and patchy extinctions and GBM types. They define felsic layers corresponding to the $\mathrm{S}_{0 / 1 / 2}$ foliation in BIF and $\mathrm{S}_{2}$ in metagranodiorites. In syn- $\mathrm{D}_{2}$ clinopyroxene syenites, quartz fabrics consist of magmatic quartz2 clasts in outer zones. They are syn- $\mathrm{D}_{2}$ quartz2 $(\leq 500 \mu \mathrm{m})$ types, hypidiomorphic $\sim$ parallel to the $\mathrm{L}_{2}$ actinolite lineation and contribute in $\mathrm{S}_{2}$ foliation. Above quartz2 types display the quartz3 BLG crystal plastic deformation, suggesting the existence of late-tectonic phase that occurred after the cooled stage under low-thermal condition $\left(<400^{\circ} \mathrm{C}\right)$.

In inner zones, quartz fabrics are well developed quartz3 dynamic recrystallized blast types (Figures 6). Magmatic relict quartz1 in metagranodiorites, metamorphic quartz2 blasts in metagranodiorites and BIF as well as quartz 2 in syn- $\mathrm{D}_{2}$ clinopyroxene syenites are recrystallized into quartz $3(\leq 200 \mu \mathrm{m})$ that ranges from GBM to GBAR types, suggesting their occurrence at middle- to higher-thermal conditions estimated between $500-850{ }^{\circ} \mathrm{C}$. These quartz 3 form the shear zone felsic layers that define S-C structures and in favourable cases, $\mathrm{S}_{3}$ schistosities. 


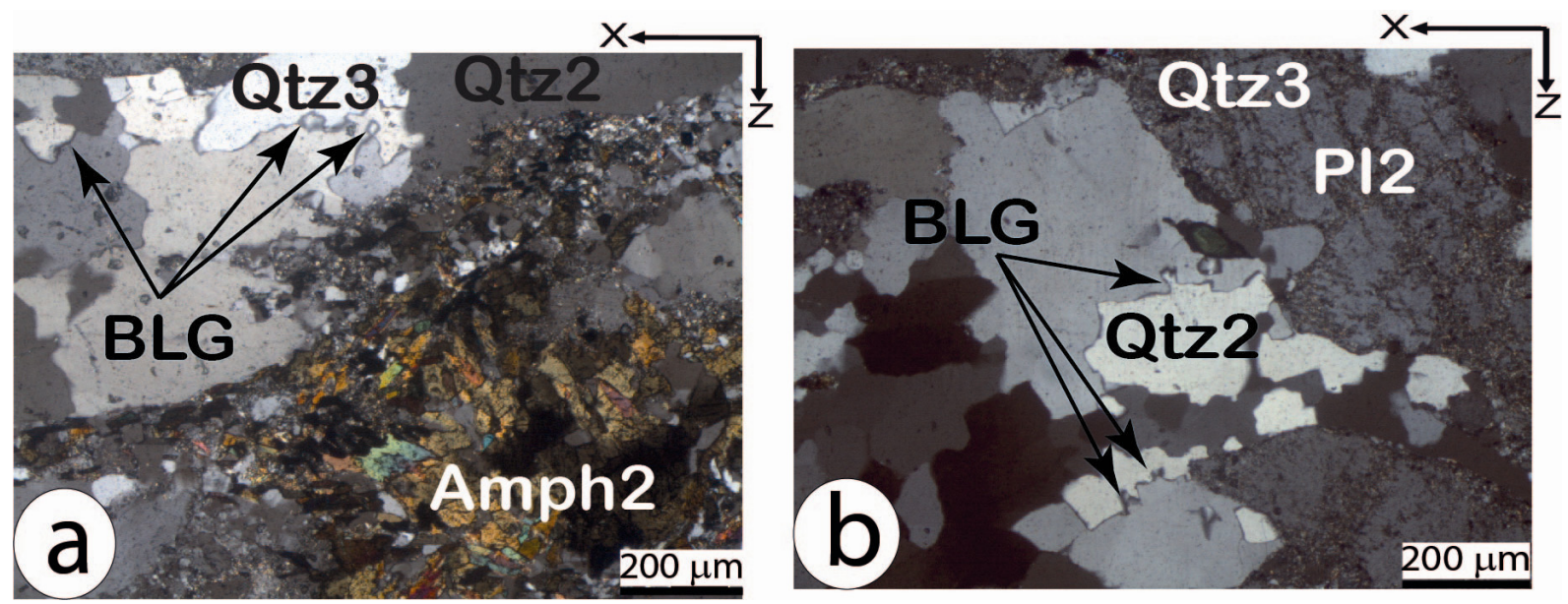

Figure 5. Quartz BLG to SGR dynamic recrystallization features in metagranodiorite protoliths. BLG: Bulging recrystallization (Low temperature). (a, b) displays the quartz BLG in metagranodiorite protolith. BLG (Low temperature); SGR: Sub grain rotation recrystallization (Medium temperature)

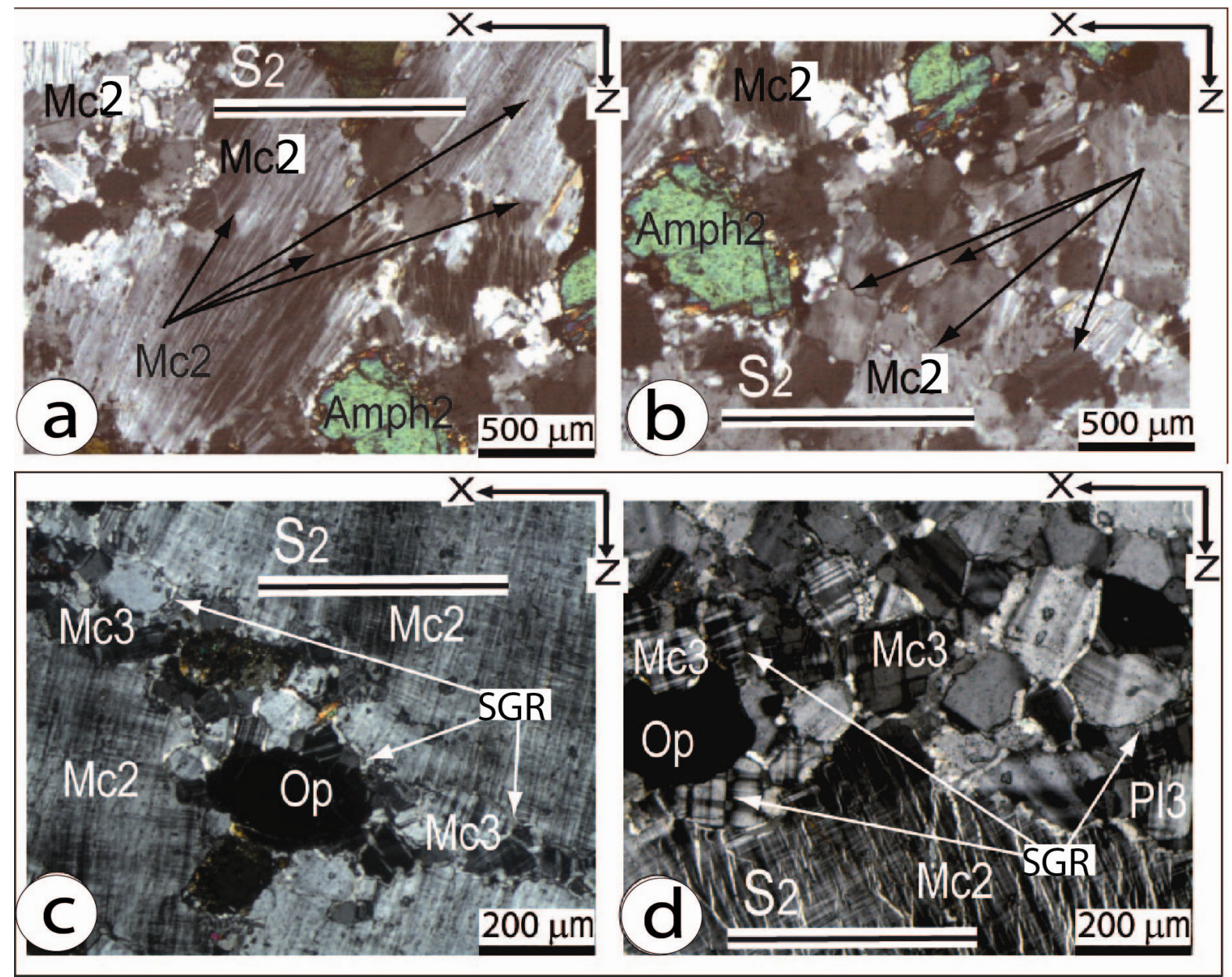

Figure 6. Feldspar BLG to SGR dynamic recrystallization features in synkinematic clinopyroxene syenite protoliths. BLG: Bulging recrystallization (Low temperature). (a, b) displays the quartz BLG and kinked microcline in syenite protolith. (c, d) show microcline SGR in syenites protolith. BLG (Low temperature); SGR: Sub grain rotation recrystallization (Medium temperature) 


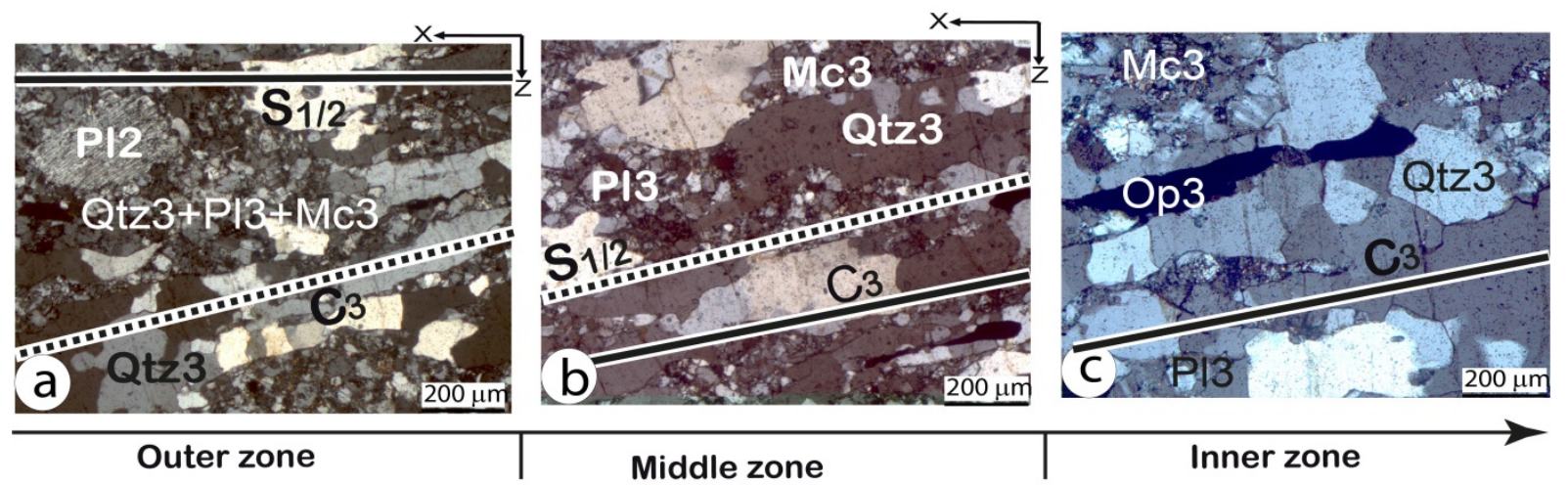

Figure 7. Quartz SGR, GBM and SGAR dynamic recrystallization features from outer to inner shear zones. (a)

Quartz3 SGR-GBM, S-C structure and preserved plagioclase2 in outer zone. (b) Quartz3 SGR-GBM, S-C structure and feldspar3 SGR in middle zone. (c) Quartz3 GBAR, feldspar3 SGR-GBM and S3 schistosity. Note the recrystallization feature evolutions in agreement with increasing temperature from outer to inner shear zones. Major extension of quartz blasts along $\mathrm{X}$ axis, indicates $\sigma 3$ orientations, euhedral quartz blasts with triple point junctions apparently undeformed but representing quartz highest deformation stage (c). BLG (Low temperature);

SGR: Sub grain rotation recrystallization (Medium temperature). GBM: Grain boundary migration (High temperature). SGAR: Sub grain area reduction (Highest temperature)

\subsubsection{Feldspars}

Feldspars show different dynamic recrystallization features in $\mathrm{NyC}$ shear zones and characterized the $\mathrm{D}_{3}$ phase (Figures 7,8). Feldspar fabrics and dynamic recrystallization features are better expressed in synkinematic syenites than in metagranodiorites. They include magmatic relict phenoclasts and recrystallized blasts. Feldspar1 phenoclasts $\left(\geq 2 \mathrm{~mm}\right.$ ) show cracked minerals with kinked twins that still represent $\mathrm{D}_{1}$ and $\mathrm{S}_{1}$ (Figures $7 \mathrm{a}-\mathrm{d}, 8 \mathrm{a}-\mathrm{d}$ ). They are recrystallized in feldspar2 blasts $(\leq 500 \mu \mathrm{m})$ forming felsic layers, equivalent to $S_{2}$ foliation. Feldspar2 is dynamically recrystallized in feldspar 3 during $\mathrm{D}_{3}$. This crystal plastic deformation started by kink bands, then grew outer and along cracks and continue towards the centre of feldspar2 old clasts and blasts in feldspar3, until their complete disappearance (Figures 8e, f). Feldspar3 $(\leq 200 \mu \mathrm{m})$ is represented by kinked clasts, type-1 to type-2 SGR and GBM blasts bordered by less pronounced SGR shape anisotropy to SGAR (Figures 8g, h). Feldspar3 define with quartz3, felsic layers equivalent to $\mathrm{S}_{3}$ schistosity and define S-C structures. These crystal plastic deformations suggest their recrystallization at higher thermal condition estimated between $500-850{ }^{\circ} \mathrm{C}$. Brittle feldspar characterized $\mathrm{D}_{4}$ and occurs under low-temperatures $\left(<450{ }^{\circ} \mathrm{C}\right)$ conditions.

\subsubsection{Amphibole}

Actinolites provide several fabrics that described their deformations and specially, dynamic recrystallization features in synkinematic clinopyroxene syenite protoliths and shear zones (Figures 9). Actinolites define the $\mathrm{S}_{2}$ foliation as well as the $\mathrm{L}_{2}$ mineral lineation. Its $\mathrm{S}_{\mathrm{i}}$ internal schistosities describe various angles with the $\mathrm{S}_{\mathrm{e}}$ external schistosities equivalent to $S_{0 / 1 / 2}$ and $S_{2}$ foliations, respectively. These schistosities provide kinematic criterion of its rotations from $\mathrm{D}_{2}$ to $\mathrm{D}_{3}$. In shear zones, actinolite2 dynamically recrystallized define fine SGR amphibole3 blasts displaying S-C structures. These amphibole3 suggest at least their emplacement under amphibolite-granulite facies $\left(500-850{ }^{\circ} \mathrm{C}\right)$ conditions. Brittle amphiboles as well as feldspars provide the brittle and post-Eburnean/Transamazonian crystal plastic deformation features (Figure 9a). These amphibole brittle fabrics occurred under low-temperature $\left(<450^{\circ} \mathrm{C}\right)$ conditions, lower than in shear zones. 


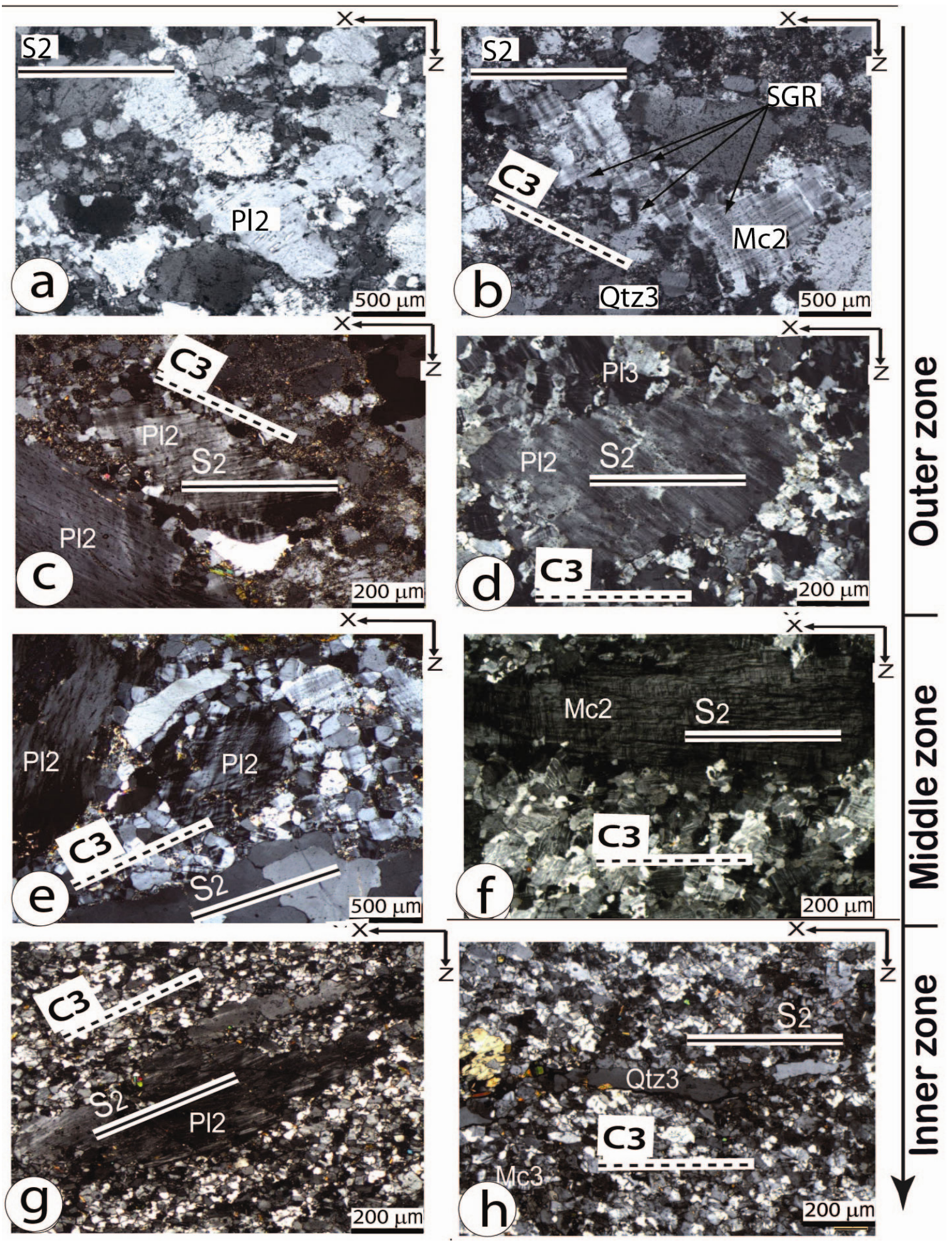

Figure 8. Feldspar SGR, GBM and SGAR dynamic recrystallization features from outer to inner shear zones. (a-d) Relict feldspar2 surrounded by feldspar3 SGR-GBM, S-C to C-S structures in outer zone. (e, f) Relict feldspar2 surrounded by feldspar3 SGR-GBM and S-C structure in middle zone. (g, h) Late relict feldspar2 to complete recrystallization of feldspar3 GBM coexisting with quartz SGAR, S-C structure and S3 schistosity. Major recrystallization of SGR feldspar3 blasts along the X axis, indicates the $\sigma 3$ orientations, the consequent anisotropies, and S2-C3 relationships. Note the recrystallization feature evolutions in agreement with increasing temperature from outer to inner shear zones BLG, SGR, GBM and SGAR thermal conditions as in Figure 8 


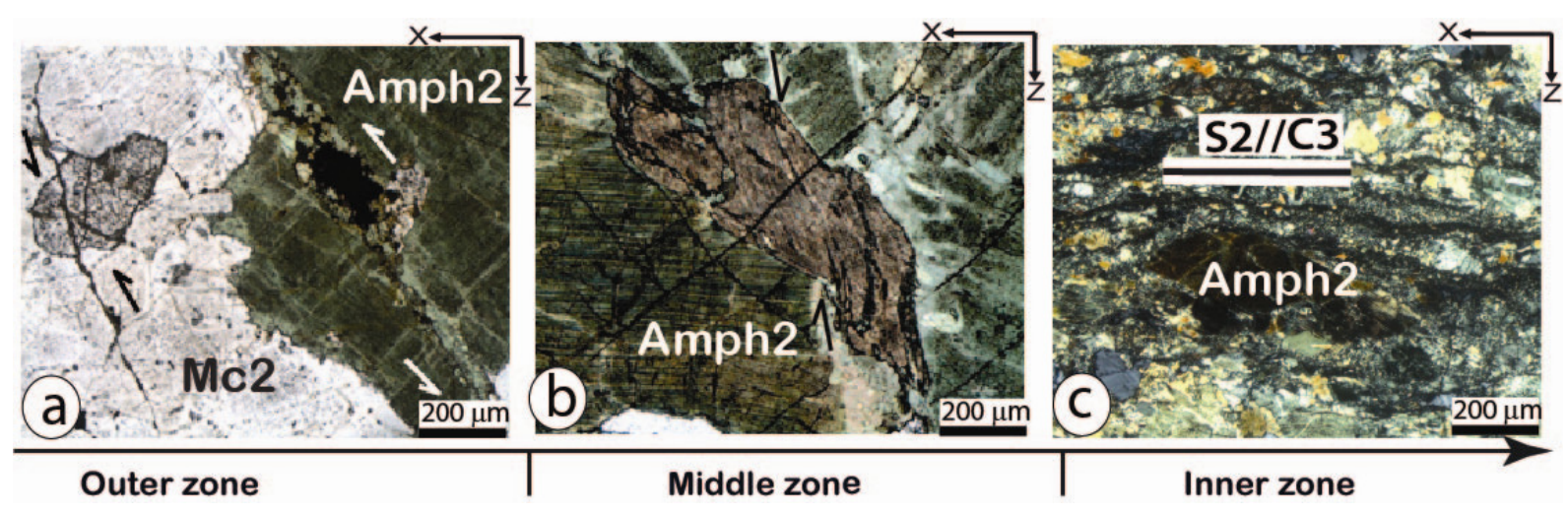

Figure 9. Amphibole dynamic recrystallization features from outer to inner shear zones in Olama (Ow284) and Akongo synkinematic syenites (Ow310). (a) Sheared amphibole and microcline suggesting cooled and faulted conditions in outer zone. (b) Shear later faulted in middle zone. (c) Actinolite SGR to SGAR in inner zone. Note the recrystallization feature evolutions in agreement with increasing temperature from outer to inner shear zones and major actinolite recrystallizations along the $\mathrm{X}$ axis, indicates $\sigma 3$ orientations, the consequent anisotropies, and $\mathrm{S}_{2}-\mathrm{C}_{3}$ relationships. BLG, SGR, GBM and SGAR thermal conditions as in Figure 8

\subsubsection{Feldspars}

Feldspars show different dynamic recrystallization features in NyC shear zones and characterized the $\mathrm{D}_{3}$ phase (Figures 7,8). Feldspar fabrics and dynamic recrystallization features are better expressed in synkinematic syenites than in metagranodiorites. They include magmatic relict phenoclasts and recrystallized blasts. Feldspar1 phenoclasts $\left(\geq 2 \mathrm{~mm}\right.$ ) show cracked minerals with kinked twins that still represent $D_{1}$ and $S_{1}$ (Figures $\left.7 a-d, 8 a-d\right)$. They are recrystallized in feldspar2 blasts $(\leq 500 \mu \mathrm{m})$ forming felsic layers, equivalent to $S_{2}$ foliation. Feldspar2 is dynamically recrystallized in feldspar3 during $\mathrm{D}_{3}$. This crystal plastic deformation started by kink bands, then grew outer and along cracks and continue towards the centre of feldspar2 old clasts and blasts in feldspar3, until their complete disappearance (Figures 8e, f). Feldspar3 $(\leq 200 \mu \mathrm{m})$ is represented by kinked clasts, type-1 to type-2 SGR and GBM blasts bordered by less pronounced SGR shape anisotropy to SGAR (Figures 8g, h). Feldspar3 define with quartz 3 , felsic layers equivalent to $\mathrm{S}_{3}$ schistosity and define S-C structures. These crystal plastic deformations suggest their recrystallization at higher thermal condition estimated between $500-850{ }^{\circ} \mathrm{C}$. Brittle feldspar characterized $\mathrm{D}_{4}$ and occurs under low-temperatures $\left(<450^{\circ} \mathrm{C}\right)$ conditions.

\subsubsection{Amphibole}

Actinolites provide several fabrics that described their deformations and specially, dynamic recrystallization features in synkinematic clinopyroxene syenite protoliths and shear zones (Figures 9). Actinolites define the $S_{2}$ foliation as well as the $L_{2}$ mineral lineation. Its $S_{i}$ internal schistosities describe various angles with the $S_{e}$ external schistosities equivalent to $S_{0 / 1 / 2}$ and $S_{2}$ foliations, respectively. These schistosities provide kinematic criterion of its rotations from $\mathrm{D}_{2}$ to $\mathrm{D}_{3}$. In shear zones, actinolite2 dynamically recrystallized define fine SGR amphibole3 blasts displaying S-C structures. These amphibole3 suggest at least their emplacement under amphibolite-granulite facies $\left(500-850{ }^{\circ} \mathrm{C}\right)$ conditions. Brittle amphiboles as well as feldspars provide the brittle and post-Eburnean/Transamazonian crystal plastic deformation features (Figure 9a). These amphibole brittle fabrics occurred under low-temperature $\left(<450^{\circ} \mathrm{C}\right)$ conditions, lower than in shear zones.

\section{Discussion}

Magnetite-bearing quartzite, metagranodiorite and synkinematic clinopyroxene syenite petrographic studies from the Kama and Akongo group reveal in the $\mathrm{NyC}$, the coexistence of the magmatic, metamorphic and retromorphic fabrics, respectively (Feybesse et al., 1998; Owona, 2008; Owona et al., 2011; Penaye et al., 2004). Granoblastic textures in BIF and metagranodiorites provide evidence of reactivation related to Eburnean/Transamazonian orogeny (Feybesse et al., 1998; Owona et al., 2011; Penaye et al., 2004). Protolith, metamorphic and retromorphic parageneses were identified in BIF and metagranodiorites, associated to their emplacement, deformation and uplift. Magmatic clasts and blasts such as quartz with undulose and patchy extinction, magnetites and detrital zircons in BIF; quartz with undulose and patchy extinction, perthitic plagioclase and antiperthitic microcline with kinked twins and biotite, opaques, apatite and zircon in metagranodiorites represent the $\mathrm{D}_{1}$ deformation phase. $\mathrm{D}_{1}$ can be interpreted as the sediment deposit as well as earliest granitoids emplacement phase that may range between $2515 \mathrm{Ma}$ in Gabon (U/Pb-Zr, Bassot et al., 1987) and $2100 \mathrm{Ma}$ in 
Cameroon (U/Pb-Zr, Penaye et al., 1993; Sm/Nd, Toteu et al., 1994). These relict clasts form the $\mathrm{S}_{1}$ foliation and the first mineral assemblages in both rock types.

Blasts of quartz, magnetite, muscovite in BIF; quartz, feldspar, amphibole, biotite and opaques in metagranodiorites; quartz, plagioclase, microcline, omphacite, actinolite, biotite, opaques, apatite, titanite, ilmenite, magnetite and zircon in syn- $\mathrm{D}_{2}$ clinopyroxene syenites defined felsic and mafic layers representing $\mathrm{S}_{2}$ foliation emplaced during $\mathrm{D}_{2}$ tectonic phase where Eburnean/Transamazonian tectonothermal event peaked under amphibolite-granulite facies between 2090-2050 Ma in Central Africa (U/Pb-Zr, Poidevin \& Pin., 1986; Bassot et al., 1987; Caen-Vachette et al., 1988; Morin et al., 1991; Nédélec et al., 1993; Toteu et al., 1994; Lerouge et al., 2006; Boniface et al., 2012). This Eburnean thermotectonic phase is responsible for the overall uralitization of pyroxene to amphibole between $2169-2000 \mathrm{Ma}$ in the $\mathrm{NyC}\left(\mathrm{Ar} / \mathrm{Ar}-\mathrm{Hbl}\right.$, Owona, 2008). $\mathrm{D}_{2}$ is accompanied by the antiperthitic K-feldspar exsolution from plagioclase, $\mathrm{F}_{2}$ folds, quartz and amphibole $\mathrm{L}_{2}$ mineral and stretching lineations (Owona, 2008; Owona et al., 2011).

$\mathrm{D}_{3}$ is characterized by crystal plastic deformations varying in term of features, intensity and thermal conditions, in protoliths and from outer to inner shear zones. BIF, metagranodiorite and syn- $\mathrm{D}_{2}$ clinopyroxene syenite protoliths show essentially BLG of quartz, brittle feldspar and amphibole. These dynamic recrystallization features attest to low and late-tectonic evidence under low-thermal conditions $\left(<350{ }^{\circ} \mathrm{C}\right)$ occurring after the cool period. This low thermal character of late-tectonic phase, confined in shear zones justifies lack of an overall $\mathrm{S}_{3}$ schistosity.

On the contrary, in typified blastomylonitic $\mathrm{D}_{3}$ shear zones and from outer to inner zones, dynamic recrystallizations features range from quartz GBM to SGAR, feldspars SGR to GBM and amphibole SGR (Kurse et al., 2001; Passchier \& Trouw, 2005; Stipp et al., 2002; Zibra, 2010, 2012; Zibra et al., 2012). $\mathrm{D}_{3}$ folded $\mathrm{S}_{0 / 1 / 2}$ and $\mathrm{S}_{2}$ foliations in $\mathrm{F}_{3}$ meso- and large-scale folds and emplaced shear zones in Central Africa from 1985-1920 $\mathrm{Ma}(\mathrm{U} / \mathrm{Pb}-\mathrm{Zr}$, Toteu et al., 1994; $\mathrm{Pb} / \mathrm{Pb}-\mathrm{Zr}$, Morin et al., 1991) to $1742 \mathrm{Ma}$ in Cameroon (Ar/Ar-Bt, Owona, 2008). Dynamic recrystallizations features define $S_{2}-C_{3}$ structures and $S_{3}$ schistosities. The coexistence of quartz GBM to SGAR and feldspars kinked, SGR to GBM and amphibole SGR dynamic recrystallizations attest that shear zone emplaced under amphibolite to granulite conditions, ranging from 500 to $850{ }^{\circ} \mathrm{C}$ (Kurse et al., 2001; Passchier \& Trouw, 2005; Stipp et al., 2002; Zibra, 2010, 2012; Zibra et al., 2012). P-T paths from the WCAFB define amphibolite to granulite conditions. They peaked at ca. $750{ }^{\circ} \mathrm{C}, 9 \mathrm{kbar}$ in Eseka migmatite (Nédélec et al., 1993); $872{ }^{\circ} \mathrm{C}, 8.22 \mathrm{kbar}$ in Olama syntectonic syenites; $662{ }^{\circ} \mathrm{C}, 14.79 \mathrm{kbar}, 1040{ }^{\circ} \mathrm{C}, 9.5 \mathrm{kbar}$ in Akongo and Nkolbewa metagabbros (Owona, 2008); $700{ }^{\circ} \mathrm{C}, 10 \mathrm{kbar}$ in Ayem metapelites and $650{ }^{\circ} \mathrm{C}, 7.5 \mathrm{kbar}$ in Ndjole-Nkan-Nkolissen amphibolites within the Ogoué-Franceville Paleoproterozoic province (Ledru et al., 1994; Feybesse et al., 1998). Indirectly, the NyC shear zones may have been active at least, from amphibolite to granulite conditions $\left(>800^{\circ} \mathrm{C},>8.5 \mathrm{Kbar}\right.$ ) (Kurse et al., 2001; Passchier \& Trouw, 2005; Stipp et al., 2002; Zibra, 2010, 2012; Zibra et al., 2012); able to reactivated quartz, feldspar and amphiboles within the WCAFB and NyC rock types that underwent the Eburnean/Transamazonian amphibolite to granulite metamorphism. This major result can be extended to the whole $\mathrm{NyC}$ in Cameroon, the whole WCAFB in Central Africa including the Paleoproterozoic Provinces such as the Carnot Basin in Central African Republic (Poidevin \& Pin., 1986; Morin et al., 1991), Ayina, Franceville and Ougoé in Gabon and West Congo in Republic of Congo (Bassot et al., 1987; Caen-Vachette et al., 1988; Morin et al., 1991; Feybesse et al., 1998) as well as in South America extensions such as the Borborema and Oaxaquia Provinces in NE Brazil and Mexico that results all, from the Eburnean/Transamazonian Congo and São Francisco cratons collision between 2400-1800 Ma (Brito Neves et al., 2000; Castaing et al., 1994; Feybesse et al., 1998; Lerouge et al., 2006; Oliveira et al., 2006; Trompette, 1994). This orogeny can be extended until $1742 \mathrm{Ma}(\mathrm{Ar} / \mathrm{Ar}-\mathrm{Bt})$ because of recent age obtained in Akongo (Ow310) synkinematic syenite (Owona, 2008). $\mathrm{D}_{4}$ was dominated by retromorphic processes related to uplift and by brittle deformation occurring under cool thermal conditions (Owona et al., 2011). Retromorphic blasts such as epidote, sericite, biotite, calcite and opaques are derived from saussuritization and damouritization of feldspars; chloritisation of biotite and alteration of amphibole under epidote-amphibolite facies.

\section{Conclusion}

Magmatic, metamorphic and retromorphic fabrics coexist in the Nyong complex rocks and are characterized by their $\mathrm{D}_{1}-\mathrm{D}_{3}$ Eburnean/Transamazonian orogeny. $\mathrm{D}_{3}$ blastomylonitic shear zones, define quartz GBM to SGAR, feldspars kinked, SGR to GBM and amphibole SGR dynamic crystallization features. They occurred due to stress regimes active under thermal conditions between amphibolite and granulite $\left(>800{ }^{\circ} \mathrm{C},>8.5 \mathrm{Kbar}\right)$ conditions between 1985-1742 $\mathrm{Ma}(\mathrm{U} / \mathrm{Pb}-\mathrm{Zr}, \mathrm{Ar} / \mathrm{Ar}-\mathrm{Bt})$. 


\section{Acknowledgments}

The authors are grateful to the DAAD for their financial support toward Owona's stay in TU-Bergakademie Freiberg, Germany and to the members of the Laboratory of Tectonophysics, Institute für Geologie.

\section{References}

Abdelsalam, G. M., Liégeois, L., \& Stern, R. J. (2002). The Saharan Metacraton. Journal of African Earth Sciences, 34, 119-136. http://dx.doi.org/10.1016/S0899-5362(02)00013-1

Bassot, J. P., Caen-Vachette, M., Kassa Mombo, C., Vialette, Y., \& Vidal, Ph. (1987). Géochronologie du socle gabonais. Rapport final (inédit) dactylographié (p. 228).

Boniface, N., Schenk, V., \& Appel, P. (2012). Paleoproterozoic eclogites of MORB-type chemistry and three Proterozoic orogenic cycles in the Ubendian Belt (Tanzania): Evidence from monazite and zircon geochronology, and geochemistry. Precambrian Research, 192-195, 16-33. http://dx.doi.org/10.1016/j.precamres.2011.10.007

Brito Neves, B., Dos Santos, E. J., \& Van Schmus, W. R. (2000). Tectonic history of the Borborema Province, Northeastern Brazil. In U. Cordani, E. J. Milani, A. Thomaz Filho, \& D. A. Campos (Eds.), Tectonic evolution of the South America (pp. 151-182). 31st Inter. Geol. Congress, Rio de Janeiro, Brazil.

Caen-Vachette, M., Vialette, Y., Bassot, J. P., \& Vidal, P. (1988). Apport de la géochronologie à la connaissance de la géologie gabonaise. Chronique de Recherche en minéralogie, 491, 35-54.

Castaing, C., Feybesse, J. L., Thieblemont, D., Triboulet, C., \& Chevremont, P. (1994). Paleogeographical reconstructions of the Pan-African/Brasiliano orogen: closure of an oceanic domain or intracontinental convergence between major blocks. Precambrian Research, 69, 327-344. http://dx.doi.org/10.1016/0301-9268(94)90095-7

Feybesse, J. L., Johan, V., Triboulet, C., Guerrot, C., Mayaga-Minkolo, F., Bouchot, V., \& Eko N‘dong, J. (1998). The West Central African belt: a model of 2.5-2.0 Ma accretion and two-phase orogenic evolution. Precambrian Research, 87, 161-216. http://dx.doi.org/10.1016/S0301-9268(97)00053-3

Guillopé, M., \& Poirier, J. P. (1979). Dynamic recryztallization during creep of single-crystalline halite: an experimental study. Journal of Geophysics Research, 84, 5557-5567. http://dx.doi.org/10.1029/JB084iB10p05557

Hirth, G., Teysser, C., \& Dunlap, W. J. (2001). An evaluation of quartzite flow laws based on comparisons between experimentally and naturally deformed rocks. Internattional Jounral of Earth Sciences, 90(31), 369-381.

Kretz, R. (1983). Symbols for rock-forming minerals. Am. Mineral., 68, 277-279.

Kurse, R., Stünitz, H., \& Kunze, K. (2001). Dynamic recrystallization processes in plagioclase porphyroclasts. Journal of Structural Geology, 23, 1781-1802. http://dx.doi.org/10.1016/S0191-8141(01)00030-X

Ledru, P., Johan, V., Milési, J. P., \& Tegyey, M. (1994). Markers of the last stages of the Palaeoproterozoic collision: evidence for a $2 \mathrm{Ga}$ continent involving circum-South Atlantic provinces. Precambrian Research, 69, 169-191. http://dx.doi.org/10.1016/0301-9268(94)90085-X

Lerouge, C., Coherie, A., Toteu, S. F., Penaye, J., Milesi, J. P., Tchameni, R., ... Deloule, E, (2006). Shrimp $\mathrm{U}-\mathrm{Pb}$ zircon age evidence for Paleoproterozoic sedimentation and 2.05 Ga syntectonic plutonism in the Nyong Group, south-western Cameroon: conse-quences for the Eburnean-Transamazonian belt of NE Brazil and Central Africa. Journal of African Earth Sciences, 44(4-5), 413-427. http://dx.doi.org/10.1016/j.jafrearsci.2005.11.010

Lopez, R., Cameron, K. L., \& Jones, N. W. (2001). Evidence for Paleoproterozoic, Grenvillian, and Pan-African age Gondwanan crust beneath northeastern Mexico. Precambrian Research, 107, 195-214. http://dx.doi.org/10.1016/S0301-9268(00)00140-6

Maurizot, P., Abessolo, A., Feybesse, A., Johan, J. L., \& Lecompte, P. (1986). Etude et prospection minière au Sud-Ouest Cameroun. Synthèse des travaux de 1978-1985. Rapport du Bureau de Recherche Géologique et Minière, 85 CNRS 066, Orléans (p. 274).

Minyem, D. (1994). Contribution à l'étude de l'évolution métamorphique et structurale du secteur Eséka-Makak (Cameroun, Département du Nyong et Kelle, Province du Centre) (p. 166). Unpublished Th., Doc. $3^{e}$ Cycle, Univ. Ydé I. 
Morin, J. Ch., Boudzoumou, F., Djama, L. M., Gioan, P., Michard, A., Mpemba-Bon, J., ... Vicat, J. P. (1991). La chaîne protérozoïque ouest Congolienne et son avant-pays au Congo: nouvelles données géochronologiques et structurales, implications en Afrique centrale. Comptes Rendus de l'Académie des Sciences, Paris, 312, 1327-1334.

Nédélec, A., Minyem, D., \& Barbey, P. (1993). High P-High T anatexis of Archaean tonalitic grey gneisses: the Eseka migmatites, Cameroon. Precambrian Research, 62, 191-205. http://dx.doi.org/10.1016/0301-9268(93)90021-S

Neves, S. P., Bruguier, O., Vauchez, A., Bosch, D., Rangel da Silva, J. M., \& Mariano, G. (2006). Timing of crust formation, deposition of supracrustal sequences, and Transamazonian and Brasiliano metamorphism in the East Pernambuco belt (Borborema Province, NE Brazil): Implications for western Gondwana assembly. Precambrian Research, 149, 197-216. http://dx.doi.org/10.1016/j.precamres.2006.06.005

Ngako, V., Affaton, P., Nnangue, J. M., \& Njanko, T. (2003). Pan-African tectonic evolution in central and southern Cameroon: transpression and transtension during sinistral shear movements. Journal of African Earth Sciences, 36, 207-214. http://dx.doi.org/10.1016/S0899-5362(03)00023-X

Ngnotue, T., Nzenti, J. P., Barbey, P., \& Tchoua, F. M. (2000). The Ntui-Bétamba high-grade gneisses: a northward extension of the Pan-African Yaounde' gneisses in Cameroon. Journal of African Earth Sciences, 31, 369-381. http://dx.doi.org/10.1016/S0899-5362(00)00094-4

Njonfang, E., Ngako, V., Moreau, Ch., Affaton, P., \& Diot, H. (2008). Restraining bends in high temperature shear zones: The "Central Cameroon Shear Zone", Central Africa. Journal of African Earth Sciences, 52, 9-20. http://dx.doi.org/10.1016/j.jafrearsci.2008.03.002

Nzenti, J. P., Kapajika, B., Wörner, G., \& Lubala, T. R. (2006). Synkinematic emplacement of granitoids in a Pan-African shear zone in Central Cameroon. Journal of African Earth Sciences, 45, 74-86. http://dx.doi.org/10.1016/j.jafrearsci.2006.01.005

Oliveira, E. P., Toteu, S. F., Araújo, M. N. C., Carvalho, M. J., Nascimento, R. S., Bueno, J. F., ... Basilici, G. (2006). Geologic correlation between the Neoproterozoic Sergipano belt (NE Brazil) and the Yaounde belt (Cameroon, Africa). Journal of African Earth Sciences, 44(4-5), 470-478. http://dx.doi.org/10.1016/j.jafrearsci.2005.11.014

Owona, S., Mvondo Ondoa, J., Ratschbacher, L., Mbola Ndzana, S. P., Tchoua, M. F., \& Ekodeck, G. E. (2011). The geometry of the Archean, Paleo- and Neoproterozoic tectonics in the Southwest Cameroon. Comptes Rendus Geosciences, 343, 312-322. http://dx.doi.org/10.1016/j.crte.2010.12.008

Owona, S. (2008). Archean, Eburnean and Pan-African features and relationships in their junction zone in the South of Yaounde (Cameroon) (p. 232). Unpublished Ph.D. Th., Univ. Douala.

Passchier, C.W., \& Trouw, R. A. J. (2005). Microtectonics. Springer.

Penaye, J., Toteu, S. F., Tchameni, R., Van Schmus, W. R., Tchakounté, J., Ganwa, A., ... Nsifa, E. N. (2004). The 2.1 Ma West Central African Belt in Cameroon: extension and evolution. Journal of African Earth Sciences, 39, 159-164. http://dx.doi.org/10.1016/j.jafrearsci.2004.07.053

Penaye, J., Toteu, S. F., Van Schmus, W. R., \& Nzenti, J. P. (1993). U/Pb and SM/Nd preliminary geohronologic data on the Yaounde series, Cameroon: Re-interpretation of granulitic rocks as the suture of a collision in the "Centrafrican belt". Comptes Rendus de l'Académie des Sciences, Paris,Série II, 317, 789-794.

Poidevin, J. L., \& Pin, C. (1986). 2 Ga U/Pb zircon dating of Mbi granodiorite (Central African Republic) and its bearing on the chronology of the Proterozoic of Central Africa. Journal of African Earth Sciences, 39, 5-6, 581-587. http://dx.doi.org/10.1016/0899-5362(86)90024-2

Rosenberg, C. L. (2004). Shear zones andmagmaascent: amodel based on a review of the Tertiary magmatism in the Alps. Tectonics, 23, 1-21. http://dx.doi.org/10.1029/2003TC001526

Stipp, M., Stünitz, H., Heilbronner, R., \& Schmid, S. M. (2002). The eastern Tonale fault zone: a 'natural laboratory' for crystal plastic deformation of quartz over a temperature range from 250 to $700{ }^{\circ} \mathrm{C}$. Journal of Structural Geology, 24(3), 1861-1884. http://dx.doi.org/10.1016/S0191-8141(02)00035-4

Tchameni, R., Mezger, K., Nsifa, N. E., \& Pouclet, A. (2001). Crustal origin of Early Proterozoic syenites in the Congo craton (Ntem complex), South Cameroon. Lithos, 57, 23-42. http://dx.doi.org/10.1016/S0024-4937(00)00072-4 
Toteu, S. F., Van Schmus, W. R., Pénaye, J., \& Nyobé, J. B. (1994). U/Pb and SM/Nd evidence for Eburnean and Pan-African high-grade metamorphism in cratonic rocks of southern of Cameroon. Precambrian Research, 67, 321-347. http://dx.doi.org/10.1016/0301-9268(94)90014-0

Toteu, S. F., Yongue, F. R., Penaye, J., Tchakounté, J., Seme Mouague, A. C., Van Schmus, W. R., ... Stendal, $\mathrm{H}$. (2006). U-Pb dating of plutonic rocks involved in the nappe tectonic in southern Cameroon: consequence for the Pan-African orogenic evolution of the central African fold belt. Journal of African Earth Sciences, 44(4-5), 479-493. http://dx.doi.org/10.1016/j.jafrearsci.2005.11.015

Trompette, R. (1994). Geology of western Gondwana (2000-500 Ma). Pan-African-Braziliano aggregation of South America and Africa. A. A. Balkema, Rotterdam, the Netherlands.

Urai, J. L., Means, W. D., \& Lister, G. S. (1986). Dynamic recrystallization of minerals. In B. E. Hobbs \& H. C. Heard (Eds.), Mineral and Rock Deformation: laboratory Studies. Geophysical Monograph, 36, 161-199. http://dx.doi.org/10.1029/GM036p0161

Vernon, R. H. (2000). Review of microstructural evidence of magmatic and solid-state flow. Electronic Geosciences, 5, 2. http://dx.doi.org/10.1007/s10069-000-0002-3

Weinberg, R. F., Sial, A. N., \& Mariano, G. (2004). Close spatial relationship between plutons and shear zones. Geology, 32, 377-380. http://dx.doi.org/10.1130/G20290.1

While, S. H. (1973). Syntectonic recrystallization and texture developpement in quartz. Nature, 244, 276-277. http://dx.doi.org/10.1038/244276a0

While, S. H. (1977). Geological significance of recovery and recrystallization processes in quartz. Tectonophysics, 39, 143-170. http://dx.doi.org/10.1016/0040-1951(77)90093-2

Zibra, I. (2012). Syndeformational granite crystallisation along the Mount Magnet Greenstone Belt, Yilgarn Craton: evidence of largescale magma-driven strain localisation during Neoarchean time. Australian Journal of Earth Sciences, 59, 793-806. http://dx.doi.org/10.1080/08120099.2012.684887

Zibra, I., Kruhl, J. H., \& Braga, R. (2010). Late Palaeozoic deformation of post-Variscan lower crust: shear zone widening due to strain localization during retrograde shearing. International Journal of Earth Sciences (Geolgische Rundschau), 99, 973-991. http://dx.doi.org/10.1007/s00531-009-0441-5

Zibra, I., Kruhl, J. H., Montanini, A., \& Tribuzio, R. (2012). Shearing of magma along a high-grade shear zone: Evolution of microstructures during the transition from magmatic to solid-state flow. Journal of Structural Geology, 37, 150-160. http://dx.doi.org/10.1016/j.jsg.2012.01.011

\section{Copyrights}

Copyright for this article is retained by the author(s), with first publication rights granted to the journal.

This is an open-access article distributed under the terms and conditions of the Creative Commons Attribution license (http://creativecommons.org/licenses/by/3.0/). 